
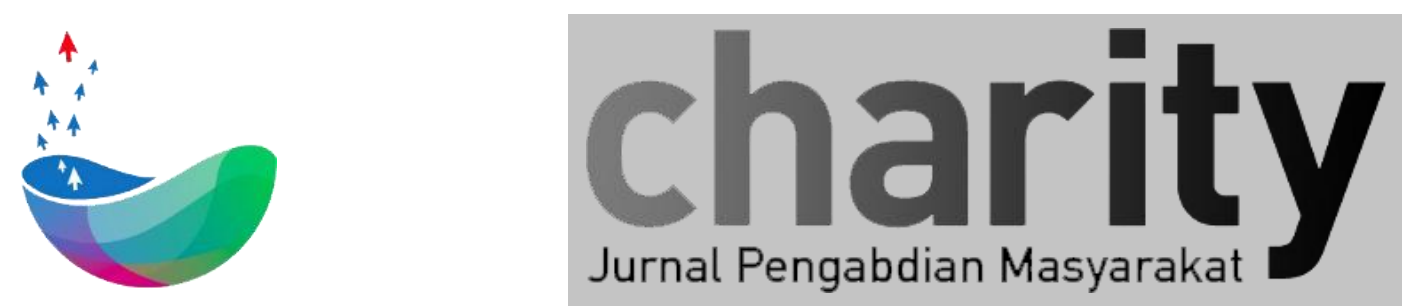

\title{
Pembangunan Kapabilitas Digital dalam Upaya Mewujudkan Smart Village Desa Citeureup Kabupaten Bandung
}

\author{
Suryatiningsih ${ }^{1}$, Aprianti Putri Sujana ${ }^{2}$, dan Luthfi Ramadani ${ }^{3}$ \\ Sistem Informasi, Fakultas Ilmu Terapan, Universitas Telkom, Jl. Telekomunikasi no. 1, Bandung 40257, Indonesia \\ ${ }^{2}$ Teknologi Rekayasa Multimedia, Fakultas Ilmu Terapan, Universitas Telkom, J1. Telekomunikasi no. 1, Bandung 40257, Indonesia \\ Sistem Informasi, Fakultas Rekayasa Industri, Universitas Telkom, J1. Telekomunikasi no. 1, Bandung 40257, Indonesia \\ *suryatiningsih@telkomuniversity.ac.id,putrisujana@telkomuniversity.ac.id, luthfi@telkomuniversity.ac.id
}

\section{INFO ARTIKEL}

Diterima 18 Desember 2021

Direvisi 20 Januari 2022

Disetujui 24 Januari 2022

Tersedia Online 24 Januari 2022

\begin{abstract}
ABSTRAK
Smart Village merupakan konsepsi sebuah desa yang didukung sistem digital terintegrasi untuk memfasilitasi agenda pembangunan daerah di Indonesia. Sistem digital sebuah smart village diantaranya menyediakan aplikasi layanan masyarakat, platform untuk aktivitas ekonomi digital, dan peningkatan kehadiran masyarakat di dunia digital (digital presence). Namun, visi digitalisasi desa ini tidak akan terwujud tanpa peningkatan kapabilitas teknologi informasi (TI) stakeholder terkait yang ada di level desa. Jurnal ini menyajikan laporan hasil intervensi terhadap kapabilitas TI di Kampung Cyber, Desa Citeureup, Kecamatan Dayeuhkolot, Kabupaten Bandung, melalui upaya berkelanjutan selama satu tahun terakhir. Secara spesifik, jurnal ini melaporkan hasil pelaksanaan tahap pertama dan kedua dari keseluruhan agenda pengabdian masyarakat berkelanjutan yang mencakup akuisisi sumber daya TI (tangible) dan peningkatan kemampuan organisasi dan manajemen TI (intangible) di level desa. Secara umum, pada tahap pertama telah diidentifikasi permasalahan yang ada di Kampung Cyber di Desa Citeureup yang diikuti dengan perumusan konsep strategis smart village Desa Citeureup. Pada tahap kedua, telah dilakukan intervensi terhadap kapabilitas digital sektor ekonomi di Usaha Mikro Kecil dan Menengah (UMKM) di Desa Citeureup.
\end{abstract}

Keyword: Kapabilitas digital, kampung cyber, Smart Village, konsep strategis pembangunan desa.

\author{
Korespondensi: \\ Suryatiningsih: Sistem Informasi, Fakultas Ilmu Terapan, Universitas Telkom, \\ Jl. Telekomunikasi no. 1, Bandung 40257, \\ E-mail : suryatiningsih@telkomuniversity.ac.id \\ ORCID ID: \\ Penulis Pertama: Nama Penulis Ke-1 \\ https://doi.org/xxx \\ Paper_reg_number xxx (C) The Authors. Published by Directorate of Research and Community Service, Telkom \\ University. \\ This is an open access article under the $\mathrm{xxx}$ license (https://creativecommons.org/licenses/xxx)
}




\section{Pendahuluan}

Salah satu upaya strategis nasional dalam penyetaraan pembangunan di Indonesia adalah penguatan peran dan fungsi desa dalam berbagai aspek pembangunan seperti ekonomi, pendidikan, kesehatan, dan sosial. Tidak terkecuali di Kabupaten Bandung, Provinsi Jawa Barat, dimana kabupaten ini memiliki 31 kecamatan, 10 kelurahan, dan 270 desa, yang saat ini masih memiliki rentang pembangunan yang sangat beragam [1]. Termasuk salah satunya Desa Citeureup, Kecamatan Dayeuhkolot, yang walaupun berada di wilayah satelit Kota Bandung, namun masih menghadapi permasalahan pembangunan seperti kemiskinan, ketimpangan ekonomi, dan lingkungan kumuh.

Universitas Telkom, yang terletak tepat di sebelah Desa Citeureup (Gambar 1), melalui kegiatan pengabdian masyarakat ini berupaya untuk memfasilitasi upaya pembangunan tingkat desa. Secara spesifik, pengabdian masyarakat ini mendorong peran Teknologi Informasi (TI) untuk percepatan program pembangunan desa. Hal ini sejalan dengan upaya pemangku kepentingan di Desa Citeureup yang secara fisik telah memulai inisiatif melalui pembangunan fasilitas bernama "Kampung Cyber". Identifikasi permasalahan inti dalam aspek TI di Kampung Cyber (secara khusus) maupun Desa Citeureup (secara umum) adalah belum adanya konsep program dan strategi dalam inisiatif Kampung Cyber Desa Citeureup. Saat ini juga belum ada pembagian peran pengelolaan dari sisi organisasi (termasuk kedinasan) maupun sisi manajemen dalam inisiatif Kampung Cyber Desa Citeureup. Selain itu, secara fisik (aplikasi dan perangkat) maupun nonfisik (skill dan prosedur), sisi TI hampir tidak ada di Kampung Cyber Desa Citeureup.

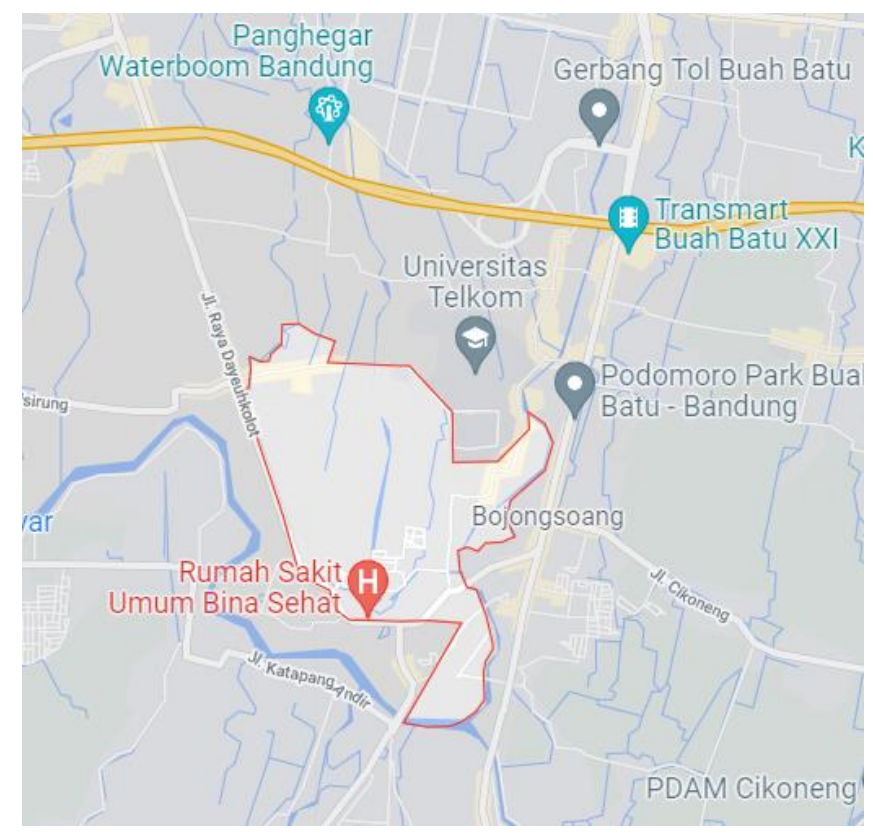

Gambar 1 Peta Wilayah Desa Citeureup (sumber: maps.google.com)

Berdasarkan kebutuhan di atas, solusi yang ditawarkan bersifat komprehensif berbasis kapabilitas digital berbasis komunitas [2]. Secara spesifik, kegiatan pengabdian masyarakat mencakup: 
1. Pendampingan dalam pengembangan konsep program dan strategi Kampung Cyber Desa Citeureup dalam bentuk peningkatan kompetensi dan pengembangan dokumen rencana strategis terkait.

2. Pendampingan dalam strategi pengelolaan Kampung Cyber Desa Citeureup baik dari sisi organisasi (termasuk kedinasan) maupun sisi manajemen.

3. Keikutsertaan Universitas Telkom untuk mengembangkan dan mengimplementasikan beberapa inisiatif TI untuk Kampung Cyber sebagai batu loncatan bagi pihak desa di tahun-tahun ke depan.

\section{Metodologi}

Pengabdian masyarakat ini dilaksanakan dengan metode intervensi langsung dengan masyarakat sasar [3]. Adapun tahapan pelaksanaan pengabdian masyarakat adalah sebagai berikut:

1. Analisis kondisi

Analisis kondisi objek sasar dilakukan dengan melakukan wawancara dan Forum Group Discussion (FGD) dengan staf dan masyarakat Desa Citeureup. Selain itu, dilakukan pengumpulan dokumen untuk data berikut:

a. Kondisi Indeks Desa Membangun (IDM) Desa Citeureup per indikator (ekonomi, sosial dan ekologi)

b. Kepadatan penduduk

c. Produk Unggulan Desa

d. Program Kerja Tahunan

e. Program yang diberikan KOMINFO yang dapat diterapkan di Desa/Kampung Cyber

2. Pengembangan konsep kampung cyber untuk mendukung smart village di Desa Citeureup

Berdasarkan data yang dikumpulkan sebelumnya, disusun sebuah konsep kampung cyber yang mencakup:

a. Penilaian kondisi eksisting terhadap indikator-indikator pembangunan di Desa Citeureup

b. Prioritas terhadap indikator-indikator pembangunan di Desa Citeureup

c. Penyusunan rencana kerja/inisiatif TI, kebutuhan skill, kebutuhan sumber daya, kebutuhan aspek organisasi, dan Key Performance Indicator (KPI)

d. Penyusunan timeline/roadmap

3. Pembangunan solusi TI.

Berdasarkan konsep kampung cyber tersebut, dipilih beberapa inisiatif TI yang dapat dibangun oleh Universitas Telkom sebagai pilot project atau solusi awal konten digital (media dan sistem informasi) untuk Desa Citeureup.

4. Pelatihan dan pendampingan eksekusi konsep kampung cyber.

5. Evaluasi program pengabdian masyarakat dan rencana keberlanjutan kampung cyber. 


\section{Hasil dan Pembahasan}

Konsep dan rencana strategis smart village Desa Citeureup menyasar berbagai sektor mencakup administrasi pemerintahan desa, pelayanan masyarakat, ekonomi digital, pendidikan, dan kesehatan. Konsep dan rencana strategis kemudian dituangkan ke sebuah roadmap yang diilustrasikan di Gambar 2.

$$
\begin{gathered}
\text { Roadmap } \\
\text { Program Pengabdian Masyarakat Kampung Cyber Citeureup (2020 - 2023) }
\end{gathered}
$$

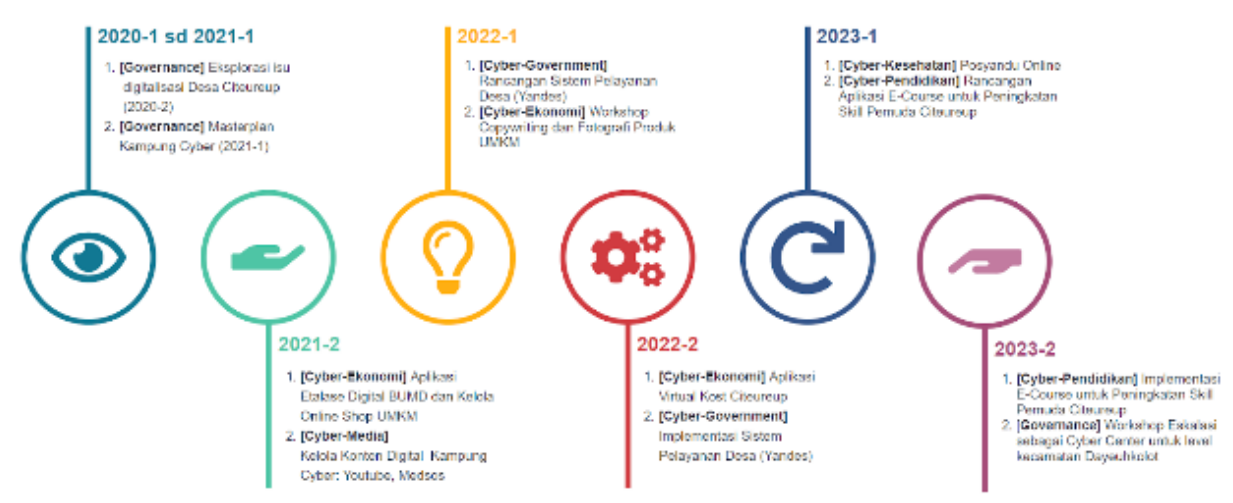

Gambar 2. Tahapan Pengabdian Masyarakat Kampung Cyber Desa Citeureup

Sesuai Gambar 2, pelaksanaan program berbasis multisektoral sebagai upaya membantu meningkatkan perkembangan masyarakat di berbagai sektor seperti administrasi, ekonomi, sosial dan ekologi. Implementasi dari setiap inisiatif disesuaikan dengan kebutuhan di masing-masing sektor tersebut, sehingga nantinya akan menciptakan IDM di tingkat "mandiri" sebagai representasi ketercapaian indikator suatu smart village [4].

Roadmap tersebut disesuaikan dengan kebutuhan masyarakat desa. Sebagai contoh, prioritas awal dari Desa Citeureup adalah peningkatan aktivitas ekonomi masyarakat desa yang saat ini sangat terdampak akan pandemi COVID-19 melalui pembangunan kemampuan ekonomi digital.

Inisiatif sektor ekonomi ini kemudian disesuaikan dengan permintaan stakeholder di Kampung Cyber Desa Citeureup untuk membuat Etalase UMKM/BUMDES. Etalase digital ini dikembangkan dengan tahapan sebagai berikut:

1. Menyiapkan database profil profuk dan pelaku usaha di Desa Citeureup

2. Melakukan pengelompokkan bidang usaha

3. Validasi permasalahan seputar BUMDES kepada pelaku UMKM

4. Desain prototipe produk digital untuk Etalase BUMDES

5. Usability testing

6. Implementasi dan sosialisasi produk digital

Etalase digital tersebut merupakan padanan dari aktivitas pelatihan UMKM di ekonomi digital, terutama dalam platform online shop yang populer di Kab/Kota Bandung (mis. Shopee, Tokopedia). Tim pengabdian masyarakat kami lalu melakukan pendampingan kepada UMKM tersebut 
dalam menggunakan platform online shop dan mengevaluasi peningkatan transaksi jual-beli yang diperoleh.

\section{Evaluasi}

Sebagai evaluasi, tim kami melakukan survey feedback baik dalam kuesioner maupun wawancara personal. Khusus untuk kuesioner, Tabel 1 menyajikan laporan singkat hasil evaluasi program. Secara umum, kegiatan ini dinilai bermanfaat dan diikuti secara antusias oleh para perwakilan di Kampung Cyber. Perwakilan ini terdiri dari Ketua Bumdes Desa Citeureup, Ketua Kampung Cyber, Perwakilan Dinas Kominfo Kabupaten Bandung, Perwakilan Pengurus Desa Citeureup, dan masyarakat Desa Citeureup.

\section{Kesimpulan dan Keberlanjutan}

Smart Village di Desa Citeureup merupakan upaya yang terintegrasi untuk memfasilitasi agenda pembangunan daerah mulai dari level paling bawah yaitu desa. Setelah dilakukan analisis potensi dan isu yang ada di masyarakat sasar, pelaksanaan digitalisasi Desa Citeureup dilakukan secara komprehensif yang terdiri dari beberapa tahap, yang mencakup analisis kondisi, pengembangan konsep dan roadmap kampung cyber untuk mendukung smart village di Desa Citeureup, dan pelaksanaan inisiatif-inisiatif smart village yang pada saat ini dimulai dari sektor ekonomi.

Sesuai dengan konsep dan roadmap yang disusun, inisiatif sektor ekonomi desa akan dilanjutkan dengan penguatan administrasi pemerintahan desa, pembangunan media dan komunikasi, dan penguatan sektor kesehatan dan pendidikan berbasis digital.

Tabel 1 Evaluasi Program (Kuesioner)

\begin{tabular}{|c|c|c|c|}
\hline No. & Penilaian Terhadap Program PKM & Setuju & $\begin{array}{l}\text { Sangat } \\
\text { Setuju }\end{array}$ \\
\hline 1 & Program pengabdian masyarakat ini sudah sesuai dengan tujuan. & 10 & 5 \\
\hline 2 & Program pengabdian masyarakat ini sudah sesuai dengan kebutuhan masyarakat. & 8 & 7 \\
\hline 3 & Waktu pelaksanaan program pengabdian masyarakat ini relatif telah mencukupi. & 12 & 3 \\
\hline 4 & $\begin{array}{l}\text { Dosen dan mahasiswa Universitas Telkom bersikap ramah, cepat dan tanggap } \\
\text { membantu selama kegiatan. }\end{array}$ & 4 & 11 \\
\hline 5 & Masyarakat menerima dan mengharapkan keberlanjutan pengabdian masyarakat. & 6 & 9 \\
\hline \multicolumn{3}{|c|}{ Jumlah \% Setuju \& Sangat Setuju } & $100 \%$ \\
\hline
\end{tabular}

\section{DAFTAR PUSTAKA}

[1] Badan Pusat dan Statistik Kabupaten Bandung, 2020, [Online]. Available: https://bandungkab.bps.go.id/

[2] L. Li, F. Su, W. Zhang, and J. Y. Mao, "Digital transformation by SME entrepreneurs: A capability perspective," Information Systems Journal, vol. 28, no. 6, pp. 1129-1157, 2018.

[3] M. M. Edwards and A. Haines, "Evaluating smart growth: Implications for small communities," Journal of Planning Education and Research, vol. 27, no. 1, pp. 49-64, 2007.

[4] P. W. Maja, J. Meyer, and S. Von Solms, "Development of Smart Rural Village Indicators in Line with Industry 4.0," IEEE Access, vol. 8, no. 152017, pp. 152017-152033, 2020. 